\title{
Isolated Pancreatic Islets: Features of Technology of Fixation and Embedding of Islets and of Insulin Staining in B-Cells
}

\author{
Meyramov GG*, Shaybek AS, Kartbaeva GT, Tykezhanova GM, Meyramova Abdraimova AG and \\ Zhumagalieva ZZ \\ Family Diabetes Research Group, Karaganda, Kazakhstan \\ *Corresponding author: Meyramov GG, Family Diabetes Research Group, Karaganda, Kazakhstan
}

\begin{tabular}{|c|c|}
\hline ARTICLE INFO & ABSTRACT \\
\hline Received: 輩 June 19, 2019 & Citation: Meyramov GG, Shaybek AS, Kartbaeva GT, Tykezhanova GM, Meyramova \\
\hline Published: 幽 June 26, 2019 & $\begin{array}{l}\text { Abdraimova AG, Zhumagalieva ZZ. Isolated Pancreatic Islets: Features of Technology of } \\
\text { Fixation and Embedding of Islets and of Insulin Staining in B-Cells. Biomed J Sci \& Tech } \\
\text { Res 19(2)-2019. BJSTR. MS.ID.003260. }\end{array}$ \\
\hline
\end{tabular}

\section{Introduction}

For investigations of effects of various chemicals or drugs on pancreatic $\beta$-cells it is preferably to use the tissue culture method of isolated pancreatic islets (PI) which possess two important advantages in compared with model in vivo:

a) It is possible to investigate direct effect on $\beta$-cells;

b) Opportunity to investigate effect of precisely defined concentrations of studied substance directly on the PI. We propose improvements of fixation, paraffin embedding and staining of sections of isolated pancreatic islets, which can significantly to improve the results.

Material and Methods

16 neonatal rats 4-5 days old and 6 adult rats were used.

Method of isolation of PI [1] from pancreas tissue was used:

a) Pancreas of rats were treated by $2 \%$ solution of collagenase in Hanks solution 3 times for 3 minutes at temperature of $+37^{\circ} \mathrm{C}$ and $\mathrm{pH}=7.33-7.40$;

b) Washing in cold Hanks solution for 30 seconds 3 times;

c) Separation in the density gradient of Dextran or manual selection of islets;

d) Washing in Hanks solution for 1 min. 2 times;
e) Visual manual selection of isolated PI;
f) Centrifugation 400-500 rpm per min.;
g) Cultivation in medium $199+5 \%$ bovin serum $+5.5 \%$ glucose for 6 hours;

h) Fixation in Bouin liquid (picric acid sol.30 $\mathrm{ml}+40 \%$ neutral formalin $10 \mathrm{ml}+$ acetic acid $2 \mathrm{ml}$ ) for 45-60 minutes (24h fixation of pancreas tissue);

i) Wash in $70^{\circ}$ alcohol 2 times; 10) fill in paraffin;

Staining of Paraffin Sections by Histochemical Methods for Staining of Insulin and Zinc-Insulin Complex in $\beta$-Cells as:

1) Aldehyde-fuchsine method;

2) Fluorescent Diethylpseudoisocyanine method

3) Immunohistochemical methods; and

4) High specific for Zinc fluorescent method of staining by 8PTSQ (8-para (toluenesulhonylamino) quinolin [2-10].

\section{Recommendations for Procedure of Embedding of PI in} Paraffin:

a) Liquid paraffin is poured into a plastic tube (diameter 1 $\mathrm{cm}$, height $-2 \mathrm{~cm}$ ) in a water bath at $56^{\circ} \mathrm{C}$; 
b) To collect suspension of PI into a pipette (or 1-2 ml syringe);

c) Lower the end of the needle of syringe into paraffin at the level of 0.3-0.4 cm from the bottom of the tube; Slowly perform 2 actions:

i. Squeezing the suspension into a tube with paraffin;

ii. Simultaneous slow raising of syringe up to the level of 0.5 $\mathrm{cm}$ from the top of the tube;

d) Then remove the tube from the water bath.

Thanks to this Technology:

1) Islets are evenly located over the entire height of the paraffin block;

2) It is possible maximally prevent formation of air bubbles in the paraffin near the islets

\section{Reagents}

Collagenase (Boehringer Mannheim GmbH, Germany); Diethylpseudoisocyanine (SERVA, Germany); Aldehyde-fuchsine (MERCK, Germany;) kits from DAKO for immunohistochemistry of insulin; 8PTSQ (Institute of High Pure Reagents, Moskva, Russia)

Method of staining of insulin in $\beta$-cells of PI by Aldehydefuchsine histochemical technic our modification [2-5]

1) Deparaffinization of sections in xylene $2 \mathrm{~min}$;
2) Xylene (2)- $2 \mathrm{~min}$;

3) abs. alcohol 1000 - $1 \mathrm{~min}$;

4) alcohol $80^{\circ}-2 \mathrm{~min}$;

5) Water - $2 \mathrm{~min}$;

6) Oxidation by $\mathrm{KMnO}_{4}-2 \mathrm{~min}$;

7) $2 \%$ solution of oxalic acid until discoloration;

8) dist. water - $2 \mathrm{~min}$;

9) Aldehyde fucshine - 5-6 min;

10) $70^{\circ}$ acidified alcohol (1) - dif- ferentiation;

11) $70^{\circ}$ acidified alcohol 2-differentiation;

12) dist. water - 3 min;

13) dist. water - 3 min;

14) abs. alcohol $100^{\circ}$ - 5 min.;

15) abs. alcohol $100^{\circ}-3 \mathrm{~min}$;

16) xylene - $2 \mathrm{~min}$;

17) balm.

\section{Result}

violet color of granules of insulin in $\beta$-cells (Figure 1.1)
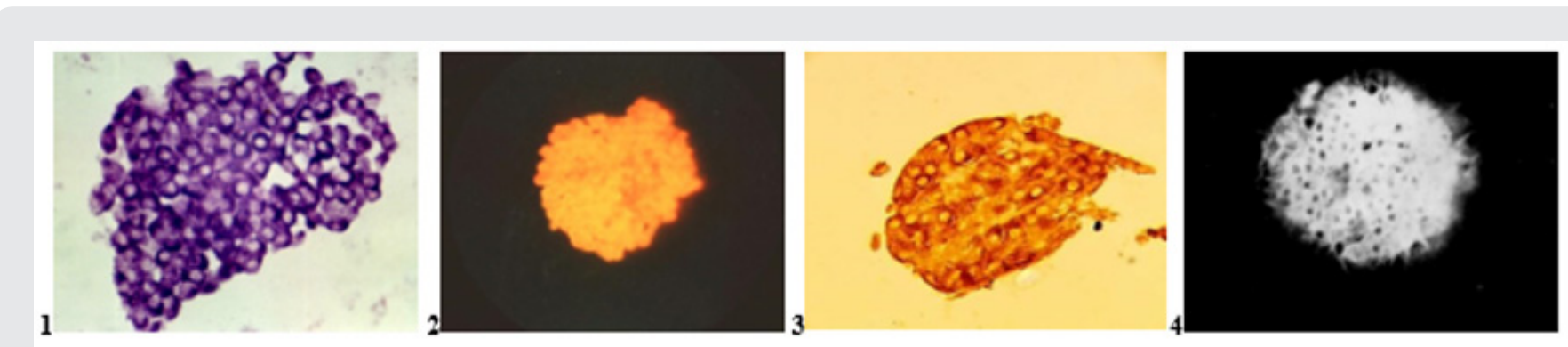

Figure 1:

1. Intact isolated pancreatic islet. Staining by Aldehyde-fucshine. Violet color of insulin in $\beta$-cells; $\times 280$;

2. Intact isolated pancreatic islet. Staining by Diethylpseudoisocyanine. Red fluorescence of insulin in $\beta$-cells; x140;

3. Intact isolated pancreatic islet. Staining by Immunohistochemical technic. Br own color of insulin in $\beta$-cells; x280;

4. Intact isolated pancreatic islet. Staining by 8PTSQ: intensive green fluorescence of Zinc-ions in $\beta$-cells; x140.

Method of Staining of Insulin in $\beta$-cells of PI by Fluorescent Diethylpseudoisocyanine Histochemical Method [6,7]
1) Deparraffinization in xylene $2 \mathrm{~min}$;
2) xylene (2)- $2 \mathrm{~min}$;
3) abs. $100^{\circ}-1 \mathrm{~min}$; alcohol - 5 minutes;
4) alcohol $90^{\circ} 4-5 \mathrm{~min}$;
5) $80^{\circ}$ alcohol - $5 \mathrm{~min}$;
6) water - $2 \mathrm{~min}$;
7) oxidation by $\mathrm{KMnO}_{4}-2 \mathrm{~min}$;
8) $2 \%$ solution of oxalic acid - until bleaching;
9) dist. water - $5 \mathrm{~min}$;
10) $0.4 \%$ aqueous solution of Diethyl-pseudoisocyanine chloride -18-20 min in refrigerator at +40Celsius;

11) $70^{\circ}$ acidified alcohol - differentiate; 
12) rinse in 2 portions of cold dist. water and store in refrigerator for 2 hours at $+4^{0}$ Celsius;

13) fluorescent microscopy (wavelength 360-370 nm; yellow excitation light filter on the lamp; locking filter on the eyepiece). Result: bright red fluorescence of insulin in $\beta$-cells (Figure 1.2).

Staining by Immunohistochemical method using of anticorps for insulin, a component of kits for insulin staining [8] (Figure 1.3). Thus, the proposed improvements of selection and handling of isolated islets as fixation, embedding in paraffin and staining of sections of tissue make it possible to obtain high-quality histological sections of isolated pancreatic islets.

\section{Conclusion}

1) Preferable is using of Bouin liquid for fixation of isolated pancreatic islets within 45-60 min.

2) Using of our technical recommendations for embedding of isolated islets into paraffin prevent:

a. Setting of islets at the bottom of paraffin block;

b. Forming of air bubbles in paraffin.

3) We recommend additional wash of islets in cold Hanks solution 2 min. after final manual selection.

\section{ISSN: 2574-1241}

DOI: 10.26717/BJSTR.2019.19.003260

Meyramov GG. Biomed J Sci \& Tech Res

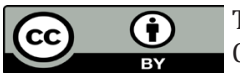

This work is licensed under Creative Commons Attribution 4.0 License

Submission Link: https://biomedres.us/submit-manuscript.php

\section{References}

1. Lacy RE, Kostianovsky M (1967) Method for the isolation of intact islets of Langerhans from the rat pancreas. Diabetes 16(1): 35-39.

2. Kvistberg D, Lester G, Lasarov A (1966) Staining of insulin with aldehyde fuchsin. J Histochem Cytochem 14: 609-611.

3. Ortman R, Forbes W, Balasubramanian A (1966) Concerning the staining properties of aldehyde basic fuchsin. J Histochem 14: 104-111.

4. Orci L (1976) Some aspects of the morphology of insulin-secreting cells. Acta Histochemistry 55(1): 147-158.

5. Meyramov GG, Konert KD, Meiramova RG (1990) Histochemical detection of insulin in the culture of endocrine pancreatic tissue using pseudoisocyanine and immunofluorescent methods. Problems of Endocrinology Moscow 36(1): 66-69.

6. Schiebler TH, Schiessler S (1959) On the Detection of Insulin with the Metachromatically Reactive Pseudoisocyanines. Histochemie 1: 445465.

7. Coalson RE (1966) Pseudoisocyanine staining of insulin and specifity of emperical islet cell stain. Stain Technol 41(2): 121-129.

8. Sternberger LA (1979) Immunocytochemistry. $2^{\text {nd }}$ (edn.). John Willey \& Sons, New York-Chichest- er-Brisbane-Toronto.

9. Meyramov GG, Tusupbekova GT, Meyramova RG (1991) The High Specific Method for Revealing of Zinc ions in Pancreatic B-cells. DIABETES, A Journal of American Diabetes Association 40(1): 65.

10. Lazaris YA, Meyramov GG (1974) K mekhanismu povreshdeniya pankreaticheskich octrovkov pri ditizonovom diabete [On the mechanisms of destruction of pancreatic islets in diabetes caused by Dithizon]. Bulletin Experimentalnoi Biologii i Meditsini. Bulletin of Experimental Biology and Medicine 3: 19-22[in Russian].

$\begin{array}{ll}\text { BIOMEDICAL } & \text { Assets of Publishing with us } \\ \text { RESEARCHES } & \text { - Global archiving of articles } \\ & \text { - Immediate, unrestricted online access } \\ & \text { - Rigorous Peer Review Process } \\ \end{array}$

